\title{
KERJASAMA ANTARDAERAH UNTUK MENINGKATKAN PEMBANGUNAN DAERAH DAN PELAYANAN PUBLIK DI KAWASAN PERBATASAN ${ }^{1}$
}

\author{
Andi Wahyudi \& Maria AP. Sari \\ Pusat Kajian dan Pendidikan dan Pelatihan Aparatur III, \\ Lembaga Administrasi Negara \\ JI. HM. Ardans, SH. (Ring Road III) Samarinda \\ Email: awahyudi2@yahoo.co.id, sari_anur@yahoo.com
}

\begin{abstract}
This study is aimed to identify regional cooperation models which are implemented by district governments within the framework of regional development, to conduct public service in the border zone, and to evaluate the effectivity of regional cooperation in achieving its goals. This study combines two research methods, i.e. descriptive analysis method with qualitative approach, and evaluation method with formal evaluation approach. Data are collected by conducting Focus Group Discussion (FGD) and supported by secondary data. Results of this study are: (1) implementation of regional cooperation among district governments in East Java and Central Java border zone is applied into regional cooperation boards (BKAD); (2) mutual interest to develop and togetherness in solving problems are basic reasons to make a regional cooperation agreement; (3) regional cooperation effectivity of the border zone is still low, due to sinergity and sincronising problems in development planning among district governments, so they affect cooperation implementation when it comes to technical operational aspects in the sectoral level.
\end{abstract}

Keywords: regional cooperation, public service, regional development, borderzone.

\section{Intisari}

Studi ini bertujuan untuk mengidentifikasi model kerjasama yang diterapkan oleh kabupaten dalam rangka pembangunan daerah dan pelayanan publik di kawasan perbatasan serta mengevaluasi sejauh mana efektivitas kerjasama itu dibandingkan tujuan dan sasaran yang telah ditetapkan. Studi ini menggunakan perpaduan metode analisis deskriptif dengan pendekatan kualitatif dan metode evaluasi dengan pendekatan evaluasi formal. Data dikumpulkan melalui FGD dan datadata sekunder. Hasil studi ini menyimpulkan bahwa (1) praktek

${ }^{1}$ Naskah diterima: 14 Oktober 2011, revisi: 26 November 2011 
kerjasama antardaerah di kawasan perbatasan Jatim dan Jateng diwujudkan dengan membentuk Badan Kerjasama Antar Daerah (BKAD); (2) kepentingan untuk maju bersama dan menyelesaikan masalah secara bersama antardaerah merupakan alasan mendasar terwujudnya kerjasama antardaerah; (3) efektivitas kerjasama tersebut masih rendah, hal ini karena masih adanya kendala sinergitas dan sinkronisasi perencanaan antardaerah sehingga berpengaruh dalam pelaksanaan kerjasama antardaerah ketika sudah menyentuh level teknis operasional di masing-masing sektor.

Kata kunci: kerjasama antar daerah, pelayanan publik, pembangunan daerah, kawasan perbatasan.

\section{A. PENDAHULUAN}

Setiap daerah pada dasarnya memiliki potensi dan keterbatasan masing-masing. Keterbatasan pemerintah daerah dalam melaksanakan pembangunan dan memberikan pelayanan publik yang menjangkau seluruh masyarakat berpotensi menyebabkan ketimpangan pemerataan hasil pembangunan dan pelayanan publik. Tidak jarang masyarakat lebih dekat dan lebih mudah mengakses daerah lain daripada ke ibukotanya sendiri, sehingga berbagai kebutuhan dasarnya seringkali juga terpenuhi dari daerah tetangganya. Dalam rangka pengembangan kawasan tersebut maka kerjasama antardaerah (KAD) yang berbatasan merupakan suatu kebutuhan untuk menutup keterbatasan yang dimiliki dalam rangka pemerataan hasil pembangunan dan meningkatkan pelayanan publik.

Di kawasan perkotaan yang telah memiliki prasarana infrastruktur yang lebih bagus serta berbagai kemudahan maka hal ini tidak terlalu menjadi persoalan, karena akses dan mobilitas masyarakat juga menjadi lebih mudah. Sehingga masyarakat memiliki banyak pilihan dalam memenuhi kebutuhannya. Namun bagi masyarakat di kawasan perdesaan atau yang jauh dari dari kota dan akses yang terbatas maka pelayanan publik menjadi sesuatu yang mahal.

Sedangkan di kawasan perbatasan yang sudah relatif dekat bahkan menjadi pusat perkotaan yang telah memiliki prasarana infrastruktur yang lebih bagus serta berbagai kemudahan ternyata masih menyisakan persoalan lain, walaupun akses dan mobilitas masyarakat juga lebih mudah, dan masyarakat memiliki banyak pilihan dalam memenuhi kebutuhannya.

Penelitian yang berkaitan dengan persoalan di kawasan perbatasan antardaerah pernah dilakukan oleh Badan Penelitian dan Pengembangan (Balitbang) Provinsi Jatim bekerja sama dengan Lembaga Penelitian Universitas Airlangga Surabaya. ${ }^{2}$ Penelitian tentang

\footnotetext{
${ }^{2}$ Anonim, 2004, Ringkasan Eksekutif Penelitian tentang Permasalahan Wilayah Perbatasan Kabupaten / Kota di Jawa Timur, Surabaya: Badan Penelitian dan Pengembangan Provinsi Jawa Timur bekerjasama dengan Lembaga Penelitian Universitas Airlangga.
} 
Permasalahan Wilayah Perbatasan Kabupaten/Kota di Jatim mengambil lokus di kawasan perbatasan Kota Surabaya dan Kabupaten Sidoarjo, menemukan berbagai persoalan di kawasan perbatasan tersebut.

Kawasan perbatasan Kota Surabaya dan Kabupaten Sidorarjo secara fisik merupakan kawasan perkotaan, dimana banyak terdapat pusat industri dan aktivitas perdagangan, serta komunitas penduduk yang padat. Di sekitar perbatasan ini terdapat kawasan industri, di antaranya adalah Kawasan Industri Rungkut (Surabaya Industrial Estate Rungkut) yang masuk wilayah Kota Surabaya. Di kawasan perbatasan ini juga terdapat Terminal Purabaya di Bungurasih, sebuah terminal angkutan darat yang menampung moda transportasi dalam kota, antar kota dan antar provinsi, yang masuk di wilayah Kabupaten Sidoarjo. Tidak jauh dari tempat ini terdapat Bandara Internasional Juanda, yang masuk wilayah Kabupaten Sidoarjo. Di kawasan tersebut juga terdapat fasilitas jalan tol yang menghubungakan wilayah Kabupaten Sidorajo dan Kota Surabaya, serta berbagai fasilitas perdagangan.

Melihat realitas fisik tersebut maka tidak terdapat kesulitas akses masyarakat terhadap fasilitas transportasi dan perekonomian secara umum untuk memenuhi kebutuhan sehari-hari. Namun ternyata persoalan lain muncul di kawasan tersebut. Hasil penelitian ini menyimpulkan bahwa berbagai permasalahan yang muncul di kawasan perbatasan tersebut yaitu:

1. Akumulasi pembangunan di pusat- pusat pertumbuhan di wilayah perbatasan tersebut berdampak terhadap kurangnya penataan dan pengembangan wilayah perbatasan;

2. Munculnya berbagai permasalahan di kawasan perbatasan, dalam dimensi sosial seperti urbanisasi, tumbuhnya banyak PKL, serta permukiman padat. Dari dimensi ekonomi muncul permasalahan padatnya lahan industri, persoalan perburuhan, berkurangnya lahan pertanian. Kemudan dari dimensi lingkungan muncul permasalahan banjir, permasalahan saluran air/sungai, sampah dan limbah industri, serta pencemaran udara;

3. Pembangunan wilayah perbatasan selama ini masih belum diorientasikan untuk melengkapi kekurangan pembangunan di pusat kota;

4. Ketimpangan pengelolaan dan pembangunan wilayah perbatasan berpotensi menyulut konflik antar pemerintah daerah yang berbatasan;

5. Konflik antardaerah perbatasan berpotensi terjadi karena distribusi bagi hasil yang tidak merata, maupun perbedaan kebijakan tata ruang masing-masing daerah di kawasan tersebut.

Keterbatasan daerah juga dimiliki oleh DKI Jakarta. Karena wilayahnya yang sudah padat dengan wilayah permukiman, industri, perdagangan, serta sebagai pusat pemerintahan maka DKI Jakarta memerlukan Bekasi (Jawa Barat) sebagai tempat pengelohan sampah terpadu (TPST). Bahkan Pemerintah DKI Jakarta masih merasa perlu menjalin kerjasama dengan Kabupaten Tangerang (Banten) untuk membangun 
TPST serupa. ${ }^{3}$ Tanpa kerjasama dengan Bekasi dan Tangerang maka sulit bagi Pemerintah DKI Jakarta untuk menampung dan mengolah sampah di wilayahnya sendiri yang dihasilkan oleh warganya.

Jauh dari keramaian kota, keterbatan yang terjadi di kawasan perdesaan memiliki karakteristik yang berbeda. Secara umum, kondisi perdesaan dicirikan oleh minimnya prasarana infrastruktur, sarana transportasi dan akses terhadap pelayanan publik dibandingkan dengan kawasan perkotaan. Oleh karena itu, kawasan perbatasan antardaerah yang berada di perdesaan memiliki permasalahan yang berbeda pula.

Persoalan di kawasan perbatasan yang memiliki karakteristik perdesaan diungkap oleh Siti Zakiyah. Bahwa kondisi umum wilayah perbatasan ini masih terkendala adanya service gap (kesenjangan pelayanan) dimana banyak fungsi pelayanan belum bisa dilaksanakan karena belum adanya lembaga yang menangani. Selain itu, lembaga yang sudah ada masih belum cukup efektif dalam menjalankan tugasnya melayani masyarakat di kawasan perbatasan, sehingga diperlukan penataan kelembagaan untuk menangani wilayah perbatasan dalam rangka percepatan pembangunan dan peningkatan pelayanan publik. ${ }^{4}$

Kawasan perbatasan antara Jawa Timur (Jatim) dan Jawa Tengah (Jateng) merupakan salah satu contoh kawasan perbatasan yang secara umum memiliki karakteristik perdesaan. Di kawasan tersebut terdapat 11 kabupaten. Enam kabupaten masuk wilayah Provinsi Jatim, yaitu Tuban, Bojonegoro, Ngawi, Magetan, Ponorogo, dan Pacitan. Dan lima kabupaten masuk dalam wilayah Provinsi Jateng, yaitu Rembang, Blora, Sragen, Karanganyar, dan Wonogiri.

Tulisan ini bertujuan untuk mengidentifikasi apa dan bagaimana praktek kerjasama antardaerah serta mengevaluasi sejauh mana efektivitas kerjasama tersebut dalam rangka memecahkan persoalan pembangunan dan pelayanan publik di kawasan perbatasan antardaerah serta manfaat yang bisa diperoleh dari kerjasama tersebut, sesuai dengan tujuan dan sasaran yang telah ditetapkan. Sampel diambil dari praktek kerjasama yang dilaksanakan antara pemerintah daerah di kawasan perbatasan Jatim dan Jateng. Dari praktek kerjasama di kawasan tersebut diharapkan ada nilai positif yang bisa menjadi contoh bagi daerah lain untuk memenuhi kebutuhan daerah dan masyarakat di kawasan perbatasan, terutama yang berkaitan dengan tugas pemerintah daerah dalam pembangunan dan pelayanan publik.

\section{B. METODE PENELITIAN}

Penelitian ini menggunakan perpaduan metode deskriptif dan metode evaluasi. Metode deskriptif dengan pendekatan kualitatif memaparkan berbagai data, informasi dan fenomena yang ada berkaitan dengan kerjasama antardaerah di lokus

${ }^{3}$ http://nasional.kompas.com/read/2009/04/03/09111381 diunduh 11 Oktober 2011

${ }^{4}$ Siti Zakiyah, Kinerja Pelayanan Publik dan Kebutuhan Penataan Kelembagaan Pengelolaan Wilayah Perbatasan di Kalimantan, dalam Jurnal Borneo Adminsitrator Vol. 3, No. 1/2007, hal. 760-761. 
penelitian. Pendekatan kualitatif menitikberatkan kreatifitas berpikir peneliti sebagai alat untuk mengolah data-data, baik data-data kualitatif maupun data-data kuantitatif.

Metode evaluasi dalam penelitian ini digunakan pendekatan evaluasi formal. Menurut William N. Dunn, evaluasi formal merupakan pendekatan yang menggunakan metode deskriptif untuk menghasilkan informasi yang valid dan cepat dipercaya mengenai hasil-hasil kebijakan atas dasar tujuan dan sasaran program kebijakan yang telah diinformasikan secara formal kepada publik. Tujuan dan sasaran tersebut bisa dilacak dari berbagai peraturan perundangan, dokumen-dokumen program serta wawancara dengan pihak yang terlibat dalam pembuatan kebijakan dan administrator.

Pengumpulan data dilakukan melalui diskusi terbatas dalam forum FGD (focus Group discussion) yang melibatkan para pejabat di lingkungan Pemerintah Provinsi Jatim dan pakar dari perguruan tinggi. Serta didukung dengan data-data sekunder yang berkaitan dengan topik penelitian. Pengambilan kesimpulan dilakukan dengan metode induksi, yaitu penarikan kesimpulan dari fenomena khusus yang ada di beberapa daerah lokus kemudian dilakukan generalisasi untuk menilai praktek kerjasama antardaerah kawasan perbatasan tersebut secara umum.

\section{TINJAUAN PUSTAKA}

Beberapa studi atau penelitian yang berkaitan dengan kerjasama antardaerah telah dilakukan. Antara lain oleh tim peneliti PKP2A I LAN. Penelitian yang berjudul Hubungan Kerjasama Pembangunan antar Daerah ini mengambil lokus di pemerintah daerah kabupaten/kota di beberapa provinsi yaitu Kota Menado (Sulut), Kota Pontianak (Kalbar), Kota Cirebon (Jabar), Kota Jambi (Jambi), Kota Palembang (Sumsel), Kota Semarang (Jateng), Kabupaten Madiun (Jatim), dan Kabupaten Badung (Bali).

Penelitian ini bertujuan mengidentifikasi model-model kerjasama antardaerah yang dapat dikembangkan dalam rangka meningkatkan pembangunan dan pelayanan publik. Hasil penelitian ini menyimpulkan 6 (enam) model yang bisa dikembangkan dalam penyelenggaraan kerjasama antardaerah, yaitu:

1. Kerjasama usaha dengan membentuk kelembagaan baru;

2. Kerjasama usaha tanpa membentuk kelembagaan baru;

3. Kerjasama non usaha dengan membentuk kelembagaan baru;

4. Kerjasama non usaha tanpa membentuk kelembagaan baru (fasilitasi pengembangan ekonomi masyarakat);

5. Kerjasama bantuan teknis (technical assistance);

6. Kerjasama kepanitiaan bersifat adhoc.

${ }_{5}^{5}$ Lihat William N. Dunn, 2003, Pengantar Analisis Kebijakan Publik, Yogyakarta: Gama Press , (Terj.), hal. $612-$ 615 , edisi kedua.

${ }^{6}$ Joni Dawud, et. al., 2003, Hubungan Kerjasama Pembangunan Antar Daerah, Bandung: PKDA I LAN, hal. 126146 
Direktorat Kerjasama Pembangunan Sektoral dan Daerah Bappenas melakukan studi dengan judul Pengembangan Kerjasama Pembangunan Sektoral dan Daerah: Persoalan dan Peluangnya. ${ }^{7}$ Studi ini menggunakan metode eksplorasi konsep dan desk study, eksplorasi empiris, pengolahan data dan analisis, serta melakukan pendalaman kasus kerjasama pembangunan sektoral dan daerah di lapangan, dengan mengambil lokus/sampel kawasan Merapi Yogyakarta, Forum Kemitraan Pembangunan Ekonomi Bali, kawasan Joglo-Semar (Yogyakarta, Solo, dan Semarang), serta pengembangan kawasan Pawonsari yang melibatkan Kabupaten Pacitan, Wonogiri dan Wonosari.

Penelitian ini mengidentifikasi pola kerjasama pembangunan yang dilakukan oleh pemerintah daerah menjadi dua yaitu kerjasama antar sektor pada daerah tertentu, dan kerjasama antardaerah. Pertama, kerjasama antar sektor pada daerah tertentu terlihat dari dua contoh kerjasama yang terjadi di Kawasan Taman Nasional Gunung Merapi (KTNGM) dan Forum Kemitraan Pembangunan Ekonomi Bali (FKPEB). Pada KTNGM di Provinsi Daerah Istimewa Yogyakarta, keterlibatan berbagai sektor pemerintah seperti Dinas Kehutanan, Dinas Pariwisata, Bappeda, mulai level pemerintah provinsi hingga pemerintah kabupaten bahkan sampai tingkat desa dalam mengurus penetapan status hukum dan membuat perencanaan tentang pengelolaan dan penataan KTNGM. Sedangkan pada FKPEB yang melibatkan berbagai stakeholder meliputi pemerintah daerah, masyarakat, dan swasta. FKPEB berperan sebagai fasilitator kelompok produsen (petani, nelayan dan pengrajin) dalam mempengaruhi proses pembuatan kebijakan agar berpihak kepada pengembangan ekonomi lokal, serta memfasilitasi peningkatan kompetensi para produsen agar produknya mampu bersaing di pasar nasional dan internasional.

Kedua, kerjasama antardaerah teridenfikasi ada empat kerjasama di beberapa daerah yang melibatkan pemerintah kabupaten/kota dan provinsi baik dalam lingkup satu provinsi maupun lintas provinsi. Yaitu (1) pengembangan kawasan segitiga Joglosemar (Jogja, Solo, dan Semarang) yang awalnya justru diinisiasi oleh swasta; (2) pengembangan kawasan Pawonsari (Pacitan, Wonogiri, dan Wonosari) yang meliputi tiga provinsi yaitu Jatim, Jateng dan Yogyakarta untuk bersamasama mengembangkan potensi dan memecahkan permasalahan bersama di kawasan tersebut; (3) kerjasama Kabupaten Badung dan Kota Denpasar dalam pengelolaan pajak hotel dan restoran; (4) pengelolaan program transmigrasi di Kalimantan Timur bekerjasama dengan pemerintah daerah pengirim transmigran seperti Jawa Barat, Jatim, dan Bali.

Penelitian ini menyimpulkan beberapa hal yaitu pertama,

${ }^{7}$ Antonius Tarigan, Kerjasama Antar Daerah (KAD) Untuk Peningkatan Penyelenggaraan Pelayanan Publik Dan Daya Saing Wilayah, dalam http://bulletin.penataanruang.net/index.asp?mod=_fullart\&idart=161, diunduh 25 Januari 2011. 
diperlukan Kerjasama Pembangunan Sektoral dan Daerah (KPSD) yang bisa dilakukan berdasarkan pokok persoalan yang sedang berkembang, seperti soal sektoral, eksternalitas daerah otonom dan fungsi interdependen antardaerah. Kedua, tanggapan yang muncul atas pokok persoalan tersebut di antaranya: (1) monitoring perkembangan sektoral dan daerah; (2) analisis kebutuhan kerjasama sektoral dan daerah. Ketiga, berbagai bentuk potensi yang dapat dimanfaatkan dalam pelaksanaan KPSD antara lain adalah: (1) keterlibatan pihak swasta; (2) kesadaran untuk saling bekerja sama; (3) inisiator kerjasama sektor dan daerah. Keempat, terdapat kendala pelaksanaan dan pengembangan KPSD, yakni: (1) perbedaan kepentingan dan prioritas; (2) besarnya harapan terhadap pemerintah pusat; (3) kuatnya peran pemerintah pusat; (4) permasalahan dana; dan (5) dokumen legalitas sebagai payung kerja sama.

Dari uraian dua penelitian di atas terlihat bahwa kedua penelitian tersebut mengidentifikasi pola-pola hubungan kerjasama antardaerah, kendala yang dihadapi, dan model hubungan kerjasama yang berpotensi atau bisa diterapkan oleh pemerintah daerah sebagai alternatif bentuk kerjasama. Sedangkan dalam tulisan ini, penulis tidak hanya mengidentifikasi praktek hubungan kerjasama sama antar daerah, tetapi juga menilai sejauh mana efektivitas praktek atau model kerjasama yang telah dilakukan oleh pemerintah daerah khususunya di kawasan perbatasan antar provinsi (Jatim dan Jateng) bagi peningkatan pembangunan daerah dan pelayanan publik di kawasan tersebut.

\section{LANDASAN TEORI DAN KEBIJAKAN}

Urgensi pelaksanaan kerjasama antar pemerintah daerah didasarkan atas beberapa pertimbangan yang rasional untuk kemajuan bersama dan karena masing-masing daerah saling memerlukan. Yeremias T. Keban memaparkan setidaknya ada tujuh alasan mengapa pemeritah daerah perlu menjalin kerjasama dengan pemerintah daerah lain, yaitu:

1. Pihak-pihak yang bekerjasama dapat membentuk kekuatan yang lebih besar. Keterbatasan daerah bisa tertutup oleh potensi yang dimiliki daerah lain, sehingga potensi atau kekuatan masingmasing daerah dapat disinergikan untuk menghadapi ancaman lingkungan atau permasalahan yang sulit apabila ditangani sendiri oleh satu daerah;

2. Pihak-pihak yang bekerjasama dapat mencapai kemajuan yang lebih tinggi. Terbuka peluang untuk transfer kepandaian, ketrampilan, dan informasi masing-masing daerah, sehingga bisa memajukan atau mengembangkan dirinya dari hasil belajar bersama;

3. Pihak-pihak yang bekerjasama dapat lebih berdaya. Kerjasama menghasilkan posisi tawar yang lebih tinggi dalam rangka memperjuangkan kepentingannya

${ }^{8}$ Yeremias T. Keban, 2009, Kerjasama Antar Pemerintah Daerah dalam Era Otonomi: Isu, Strategis, Bentuk dan Prinsip, Dapat dibuka di situs: http://www.bappenas.go.id/node/48/2258/kerjasama-antar-pemerintah-daerahdalam-era-otonomi-oleh-yeremias-t-keban-/, diunduh 25 Januari 2011. 
kepada struktur pemerintahan yang lebih tinggi;

4. Pihak-pihak yang bekerjasama dapat memperkecil atau mencegah konflik. Kerjasama berpotensi meningkatkan pengertian dan saling membantu masing-masing pihak, daerah-daerah yang semula bersaing ketat atau sudah terlibat konflik, dapat bersikap lebih toleran dan berusaha mengambil manfaat atau belajar dari konflik tersebut;

5. Masing-masing pihak lebih merasakan keadilan. Kerjasama membuka transparansi antardaerah karena masing-masing memiliki akses yang sama terhadap informasi yang dibuat atau digunakan;

6. Masing-masing pihak yang bekerjasama akan memelihara keberlanjutan penanganan bidangbidang yang dikerjasamakan. Hal ini terutama jika pelaksanaan kerjasama telah memberikan manfaat bagi masing-masing daerah, sehingga sangat terbuka peluang untuk dilakukan secara berkelanjutan;

7. Kerjasama dapat menghilangkan ego daerah. Masing-masing daerah bisa mengurangi ego kedaerahan, untuk mewujudkan visi memajukan daerah secara bersama-sama.

Beberapa isu strategis yang selama ini berpotensi untuk dikerjasamakan antarpemerintah daerah diungkapan oleh Antonius Tarigan ${ }^{9}$ di antaranya adalah:

1. Peningkatan Pelayanan Publik;2

2. Pengelolaan Kawasan Perbatasan;
3. Penanganan Tata Ruang;

4. Penanggulangan Bencana dan Penanganan Potensi Konflik;

5. Penanganan Kemiskinan dan Pengurangan Disparitas Wilayah;

6. Peningkatan peran Provinsi sebagai fasilitator dan katalisator kerjasama antardaerah.

Oleh karena itu, kerjasama antardaerah bisa diterapkan untuk berbagai isu strategis dan urgen yang ada di daerah. Gary D. Taylor ${ }^{10}$ merinci beberapa kemungkinan bentuk yang bisa diwujudkan dalam kerjasama antardaerah, yaitu:

1. Handshake Agreement, kerjasama antardaerah tanpa dokumen perjanjian formal. Bentuk kerjasama didasarkan pada komitmen dan kepercayaan yang tinggi secara politis antardaerah yang terkait.

2. Fee for service contracts (service agreements). Wujud kerjasama ini dimana satu daerah "menjual" satu bentuk pelayanan publik atau melayani masyarakat dari daerah lain. Misalnya fasilitas pendidikan, kesehatan, air bersih, listrik, dan sebagainya, dengan sistem kompensasi (harga) dan jangka waktu yang disepakati bersama.

3. Joint Agreements (pengusahaan bersama). Diperlukan keterlibatan masing-masing daerah dalam penyediaan atau pengelolaan pelayanan publik yang dilakukan secara bersama-sama.

4. Jointly-formed authorities (pembentukan otoritas bersama).

\footnotetext{
${ }^{9}$ Antonius Tarigan, op. cit

${ }^{10}$ Gary D. Taylor, sebagaimana dikutip oleh Antonius Tarigan, op. cit.

${ }^{11}$ Lihat Denhardt, Janet V. dan Robert B. Denhardt, 2007, The New Public Service: Serving, Not Steering. M.E. Sharpe, Inc., New York, hal 42-43
} 
Masing-masing daerah bersepakat membentuk lembaga yang diserahkan kepada pihak yang profesional untuk mengelolanya.

Tuntutan masyarakat terhadap pelayanan publik dan pembangunan senantiasa meningkat seiring dengan perkembangan ilmu pengetahuan dan teknologi. Janet V. Denhardt dan Robert B. Denhardt ${ }^{11}$ mengumpulkan berbagai pandangan para pakar berkaitan tentang kewarganegaraan, komunitas dan masyarakat madani, humanisme organisasional dan administrasi publik baru, dan posmodern. Pemikiran berbagai sudut pandang tersebut telah membantu merumuskan model pelayanan publik baru (new public service). Kompilasi berbagai pemikiran tersebut adalah:

1. Serve Citizens, Not Customers (melayani masyarakat, bukan pelanggan). Aparatur pemerintah lebih fokus kepada menjalin hubungan kepercayaan dan kerjasama dengan semua masyarakat, bukan dalam pengertian "customer" individual.

2. Seek the Public Interest (mencari kepentingan publik). Memberikan kontribusi kepada masyarakat secara kolektif melalui penciptaan kepentingan dan tanggung jawab bersama.

3. Value citizenship over enterpreneurship (nilai kewarganegaraan di atas kewirausahaan). Kepentingan publik yang lebih baik dikembangkan oleh aparat dan komitmen untuk memberikan kontribusi kepada masyarakat daripada manajer usaha yang bertindak seolah-olah uang publik adalah miliknya.

4. Think strategically, act democratically (berpikir strategis, bertindak demokratis). Program dan kebijakan publik bisa efektif dan tercapai melalui usaha kolektif dan proses kerjasama.

5. Recognize that accountability isn't simple (mengakui bahwa akuntabilitas tidak sederhana). Pelayan publik harus lebih penuh perhatian/atensif daripada pasar.

6. Serve rather than steer (lebih melayani daripada mengarahkan). Nilai dasar kepemimpinan public adalah membantu masyarakat mengartikulasikan kebutuhannya dan sesuai dengan kepentingan bersama daripada mengontrol atau mengarahkan masyarakat.

7. Value people, not just productivity (nilai masyarakat, bukan hanya produktivitas). Organisasi publik dan jaringan kerjanya bisa lebih berhasil apabila dilakukan melalui proses kerjasama dan berdasar kepemimpinan bersama atas respek untuk semua masyarakat.

Dalam kaitannya dengan pelayanan publik, secara umum tugas suatu negara adalah memberikan pelayanan bagi warga negaranya, bahkan pelayanan menjadi tugas terpenting dalam penyelenggaraan pemerintahan negara. Pelayanan publik, sebagimana tertuang pada Pasal 1 UU No. 25 Tahun 2009, adalah kegiatan atau rangkaian kegiatan dalam rangka pemenuhan kebutuhan pelayanan sesuai dengan peraturan perundang-undangan bagi setiap warga negara dan penduduk atas barang, jasa, dan/atau pelayanan administratif yang disediakan oleh penyelenggara 
pelayanan publik.

Berbagai landasan regulasi atau kebijakan yang bisa digunakan pemerintah daerah untuk menjalin kerjasama antardaerah dalam rangka peningkatan pembangunan dan penyelenggaraan pelayanan publik telah dikeluarkan oleh pemerintah. Mulai dari terdahulu hingga terbaru adalah:

1. Permendagri No 6 Tahun 1975 tentang Kerjasama Antar Daerah;

2. Kepmendagri Nomor 275 Tahun 1982 tentang Pedoman Kerjasama Pembangunan Antar Daerah;

3. SE-Mendagri No 193/1652/PUOD tanggal 26 April 1993 tentang Tata Cara Pembentukan Hubungan Kerjasama Antar Propinsi (Sister Province) dan Antar Kota (Sister City) Dalam dan Luar Negeri;

4. SE-Mendagri No 114/4538/PUOD tanggal 4 Desember 1993 tentang Petunjuk Pelaksana Mengenai Kerjasama Antar Daerah;

5. Undang-undang Nomor 32 Tahun 2004 tentang Pemerintahan Daerah dan;

6. Peraturan Pemerintah Nomor 50 Tahun 2007 tentang Kerjasama Antar Daerah.

7. Permendagri No. 22 Tahun 2009 tentang Petunjuk Teknis Tata Cara Kerja Sama Daerah.

UU No. 32 Tahun 2004 tentang Pemerintahan Daerah memberikan peluang untuk dilaksanakannya kerjasama pembangunan, baik dengan sesama pemerintah daerah maupun dengan pihak ketiga (publik dan juga swasta) dalam rangka meningkatkan kesejahteraan rakyat. Pemerintah daerah dapat mengadakan kerjasama dengan daerah lain yang didasarkan pada pertimbangan efisiensi dan efektivitas kerjasama antardaerah yang bertetangga.

Beberapa pasal dalam UU No. 32 Tahun 2004 secara eksplisit mengatur tentang hubungan antardaerah. Pasal 2 ayat (4) menyatakan bahwa pemerintahan daerah dalam menyelenggarakan urusan pemerintahan memiliki hubungan dengan pemerintah (pusat) dan dengan pemerintahan daerah lainnya. Hubungan tersebut, kemudian dijelaskan pada ayat (5) meliputi hubungan wewenang, keuangan, pelayanan umum, pemanfaatan sumber daya alam, dan sumber daya lainnya.

Pada Pasal 195 ayat (1) dinyatakan bahwa kerjasama antardaerah dilakukan dalam rangka meningkatkan kesejahteraan rakyat dan didasarkan pada pertimbangan efisiensi dan efektifitas dalam pelayanan publik, sinergi, dan saling menguntungkan. Bahkan Pasal 196 ayat (2) lebih tegas menyatakan bahwa kewajiban daerah dalam mengelola pelayanan publik secara bersama dengan daerah sekitranya adalah untuk menciptakan efisiensi.

Pengaturan lebih lanjut tentang hubungan kerja sama antardaerah tersebut tertuang dalam PP No. 50 Tahun 2007 tentang Tata Cara Pelaksanaan Kerja Sama Daerah. Kerjasama daerah, menurut PP No. 50 Tahun 2007, adalah kesepakatan antara gubernur dengan gubernur atau 
gubernur dengan bupati/wali kota atau antara bupati/wali kota dengan bupati/wali kota yang lain, dan atau gubernur, bupati/wali kota dengan pihak ketiga, yang dibuat secara tertulis serta menimbulkan hak dan kewajiban. Mengacu pengertian ini maka kerjasama daerah bisa dilakukan oleh pemerintah provinsi maupun kabupaten/kota dengan pemerintah provinsi dan kabupaten/kota lain.

Pemerintah provinsi dalam kerjasama antardaerah memiliki peran penting, hal ini diperkuat dengan terbitnya PP No. 19 Tahun 2010 tentang Tata Cara Pelaksanaan Tugas dan Wewenang serta Kedudukan Keuangan Gubernur Sebagai Wakil Pemerintah di Wilayah Provinsi, sebagaimana telah diubah dengan PP No. 23 Tahun 2011 tentang Perubahan Atas Peraturan Pemerintah Nomor 19 Tahun 2010 Tentang Tata Cara Pelaksanaan Tugas Dan Wewenang Serta Kedudukan Keuangan Gubernur Sebagai Wakil Pemerintah di Wilayah Provinsi.

Berdasarkan Pasal 3 PP No. 19 Tahun 2010 sebagaimana telah diubah dengan PP No. 23 Tahun 2011, gubernur sebagai wakil pemerintah pusat di daerah memiliki tugas melaksanakan urusan pemerintahan. Antara lain adalah melakukan koordinasi penyelenggaraan pemerintahan antara pemerintah daerah provinsi dengan instansi vertikal, dan antar instansi vertikal di wilayah provinsi yang bersangkutan; Koordinasi penyelenggaraan pemerintahan antara pemerintah daerah provinsi dengan pemerintah daerah kabupaten/kota di wilayah provinsi yang bersangkutan;
Koordinasi penyelenggaraan pemerintahan antar pemerintahan daerah kabupaten / kota di wilayah provinsi yang bersangkutan; Koordinasi dalam penyusunan, pelaksanaan dan pengendalian serta evaluasi dalam rangka sinkronisasi Rencana Pembangunan Jangka Panjang Daerah (RPJPD), Rencana Pembangunan Jangka Menengah Daerah (RPJMD), dan Rencana Kerja Pemerintah Daerah (RKPD) kabupaten dan kota agar mengacu pada RPJPD, RPJMD, dan RKPD provinsi serta Rencana Pembangunan Jangka Panjang Nasional (RPJPN), Rencana Pembangunan Jangka Menengah Nasional (RPJMN), dan Rencana Kerja Pemerintah (RKP) serta kebijakan pembangunan nasional yang ditetapkan oleh Pemerintah; Koordinasi pembinaan dan pengawasan penyelenggaraan tugas pembantuan di daerah provinsi dan kabupaten/kota; serta pembinaan dan pengawasan penyelenggaraan pemerintahan daerah kabupaten/kota.

Berkaitan dengan pelaksanaan kerjasama antardaerah maka gubernur berperan penting dalam mengkoordinasikan kerjasama antar kabupaten/kota di wilayah provinsinya dalam rangka sinkronisasi pembangunan di daerah. Berbagai regulasi tersebut bisa menjadi pedoman bagi daerah dalam melaksanakan kerjasama antardaerah dalam rangka memenuhi kebutuhan pembangunan daerah dan pelayanan publik yang lebih baik.

\section{E. HASIL DAN PEMBAHASAN}

Pembangunan wilayah perbatasan antardaerah merupakan 
bagian integral yang tidak terpisahkan dari pembangunan daerah secara keseluruhan. Pembangunan kawasan perbatasan antar provinsi maupun antar kabupaten/kota merupakan perwujudan pengelolaan ruang wilayah regional sebagai satu kesatuan geografi, politik, ekonomi, sosial, budaya dan pertahanan keamanan. Hal ini yang dipandang perlu untuk diimplementasikan dalam tindakan nyata oleh beberapa pemerintah kabupaten di kawasan perbatasan Jatim dan Jateng.

Regionalisasi pengembangan kawasan berkaitan dengan pelaksanaan kerjasama antardaerah bisa dilakukan dengan dua pendekatan, yaitu pendekatan spasial dan manajerial. Pendekatan spasial menekankan pada penentuan wilayah yang dijadikan kawasan strategis yang diatur dalam RTRW. Sedangkan pendekatan manajerial bisa dilakukan dalam bentuk kerjasama riil antar pemerintah daerah (government to government / G to $\mathrm{G}$ ) dan antar pelaku usaha (business to business ( B to B). ${ }^{12}$

Berkaitan dengan pelaksanaan kerjasama antar kabupaten di kawasan perbatasan Jatim dan Jateng, perumusan konsep kerjasama tersebut dilakukan oleh Bappeda, sebagai unit yang bertanggung jawab dalam urusan perencanaan dan koordinasi pembangunan daerah. Selanjutnya persoalan teknis operasional dan realisasi pelaksanaan kerjasama menjadi kewenangan SKPD masing- masing sesuai dengan bidang yang menjadi obyek kerjasama. ${ }^{13}$

\section{Bentuk Kerjasama}

Kerjasama antar kabupaten di kawasan perbatasan Jatim dan Jateng terwujud dalam dua badan kerjasama antardaerah (BKAD) dengan dukungan fasilitasi dari Pemerintah Provinsi Jatim dan Jateng. Pertama adalah BKAD Karismapawirogo yang meliputi 7 kabupaten di kawasan perbatasan wilayah tengah dan selatan. Dan yang kedua adalah BKAD Ratubangnegoro yang meliputi 4 kabupaten di kawasan perbatasan wilayah utara.

\section{a. Karismapawirogo}

BKAD Karismapawirogo adalah lembaga pelaksana kerjasama antar kabupaten yang meliputi Kabupaten Karanganyar, Kabupaten Wonogiri, Kabupaten Sragen, Kabupaten Magetan, Kabupaten Pacitan, Kabupaten Ngawi, dan Kabupaten Ponorogo. Nama Karismapawirogo merupakan akronim dari potongan nama-nama kabupaten tersebut, yang secara geografis berada di kawasan perbatasan Jatim dan Jateng wilayah tengah dan selatan. Dimana Kabupaten Pacitan (Jatim) dan Kabupaten Wonogiri (Jateng) berada pada posisi paling selatan yang memiliki potensi pantai dan laut.

Awal terbentuknya BKAD Karismapawirogo didahului dengan Kesepakatan Kerjasama antar tujuh kabupaten yang ditandatangani oleh

\footnotetext{
${ }^{12}$ FGD Kajian Pola Hubungan Kerja antar Provinsi di Kalimantan, Bappeda Provinsi Jatim, Surabaya, 28 Juni 2011. Kajian tersebut mengambil lokus utama di regional Kalimantan dan Jawa Timur merupakan salah satu sampel yang diambil sebagai lokus pembanding di luar regional Kalimantan. ${ }^{13}$ Ibid
} 
para bupati dari 7 kabupaten pada 31 Desember 2008 bertempat di Kab. Wonogiri. Kemudian kesepakatan bersama ini ditindaklanjuti dengan penerbitan Keputusan Bersama tujuh bupati pada 31 Desember 2008. Penandatanganan kedua dokumen pada tanggal yang sama tersebut mencerminkan bahwa sudah adanya kesepahaman dan persiapan jauh hari sebelumnya berkaitan dengan rencana kerjasama di kawasan tersebut.

Ruang lingkup kerjasama BKAD Karismapawirogo meliputi bidang-bidang baik yang berkaitan dengan pembangunan daerah dan pelayanan publik, yaitu: kesehatan, pertambangan dan energi, kehutanan dan perkebunan, perindustrian dan perdagangan, penanaman modal, ketenagakerjaan, pendidikan dan kebudayaan, sosial, tata ruang dan batas wilayah, pekerjaan umum, perhubungan, lingkungan hidup, pariwisata, perikanan dan kelautan, trantibum, pertanian, dan bidang lain sesuai dengan kebutuhan daerah.

Dalam rangka menjalankan organisasi dan program kerja/kegiatan BKAD maka dipilih koordinator untuk masa kerja selama 2 tahun. Kabupaten Karanganyar mendapatkan tugas sebagai koordinator pertama periode 2009-2011. Kelembagaan BKAD Karismapawirogo adalah sebagai berikut:
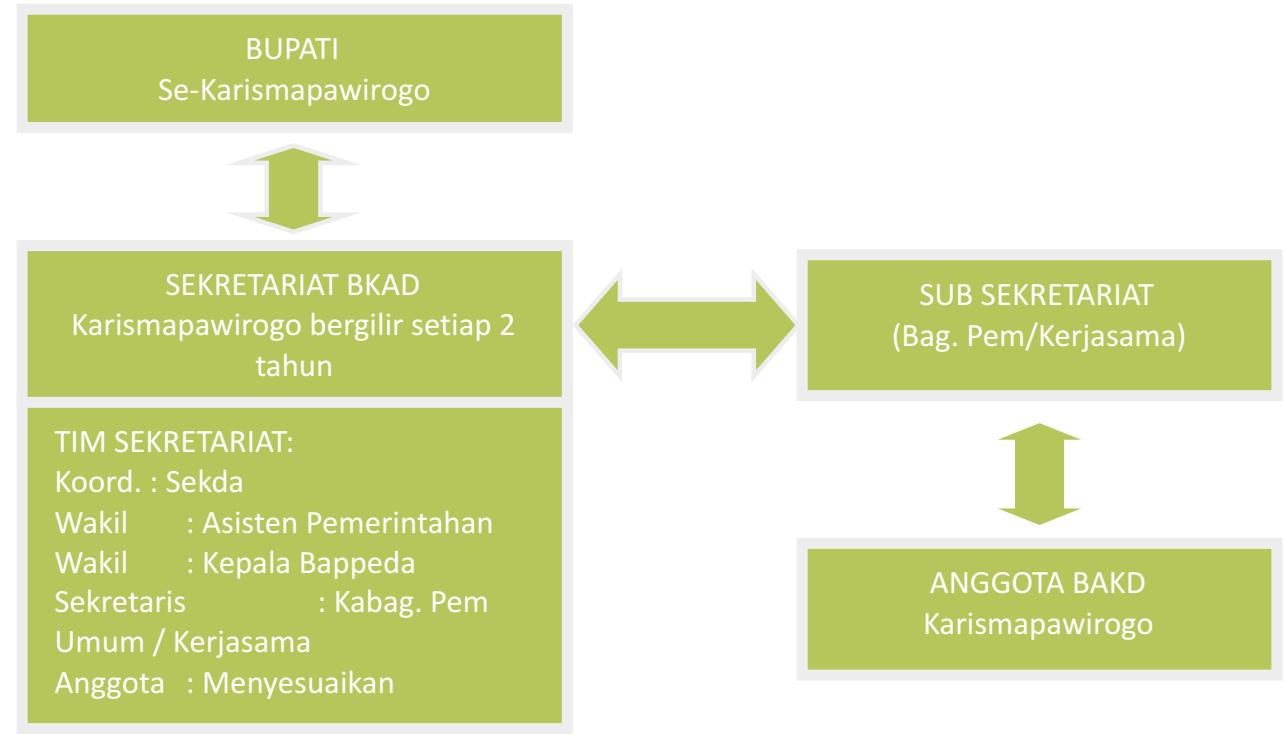

Sumber: Memory Serah Terima Koordinator BKAD Karismapawirogo 12 Mei 2009- 12 Mei 2011, 2011

Gambar 1. Bagan BKAD Karismapawirogo

Program kerja tahun 2009-2011 merupakan program kerja kepengurusan yang pertama. Oleh karena itu, program/ kegiatan pada masa kepengurusan tersebut diantaranya menyiapkan perangkat organisasi dan identifikasi permasalahan yang dihadapi oleh masing-masing kebupaten di kawasan perbatasan tersebut. 
B erdasarkan laporan kepengurusan yang pertama (20092011), beberapa program/kegiatan telah dilaksanakan sepanjang 2009 hingga $2011 .{ }^{14}$ Program/kegiatan yang telah dilaksanakan selama tahun 2009 adalah:

1. $\mathrm{P}$ e $\mathrm{m}$ e t a a $\mathrm{n} \quad(m a p p i n g)$ potensi/wilayah karismapawirogo;

2. Penjodohan/kemitraan (matching) UMKM dengan pengusaha besar;

3. Perjanjian kerjasama bidang kesehatan;

4. Launching B K A D Karismapawirogo.

Pemetaan potensi wilayah merupakan upaya untuk mengenali kondisi lingkungan internal sebagai persyaratan utama dalam perumusan kebijakan ke depan. Karena dengan kegiatan tersebut akan terlihat potensi apa saja yang dimiliki oleh masingmasing kabupaten serta permasalaan apa yang dihadapi. Identifikasi dan pemaparan potensi masing-masing daerah secara bersama dalam forum Karismapawirogo bisa direspon oleh daerah lain yang memiliki potensi dan permasalahan yang sama, maupun yang memiliki potensi lain yang bisa menutupi keterbatasan daerah lain. Macthing potensi antardaerah bisa membawa sinergi untuk kemajuan bersama, tentunya apabila ditindaklanjuti dengan kegiatan yang nyata. Sebagaimana dinyatakan oleh Yeremias T. Keban ${ }^{15}$ bahwa kekuatan antardaerah bisa disinergikan untuk menghadapi permasalahan bersama dalam rangka mencapai kemajuan bersama yang lebih tinggi.

Tabel 1. Potensi Daerah Karismapawirogo

\begin{tabular}{|l|l|c|c|c|c|c|c|c|}
\hline No. & \multicolumn{1}{|c|}{ Potensi } & Karanganyar & Wonogiri & Sragen & Magetan & Pacitan & Ngawi & Ponorogo \\
\hline 1. & Pertambangan & - & $\sqrt{ }$ & - & - & $\sqrt{ }$ & - & $\sqrt{ }$ \\
\hline 2. & $\begin{array}{l}\text { Pariwisata/ } \\
\text { budaya }\end{array}$ & $\sqrt{ }$ & $\sqrt{ }$ & $\sqrt{ }$ & $\sqrt{ }$ & $\sqrt{ }$ & $\sqrt{ }$ & $\sqrt{ }$ \\
\hline 3. & Peternakan & - & $\sqrt{ }$ & $\sqrt{ }$ & $\sqrt{ }$ & $\sqrt{ }$ & - & $\sqrt{ }$ \\
\hline 4. & $\begin{array}{l}\text { Pertanian/ } \\
\text { perkebunan }\end{array}$ & $\sqrt{ }$ & $\sqrt{ }$ & $\sqrt{ }$ & $\sqrt{ }$ & - & $\sqrt{ }$ & $\sqrt{ }$ \\
\hline 5. & Kehutanan & - & - & - & $\sqrt{ }$ & - & - & $\sqrt{ }$ \\
\hline 6. & Perikanan & - & $\sqrt{ }$ & $\sqrt{ }$ & $\sqrt{ }$ & $\sqrt{ }$ & - & $\sqrt{ }$ \\
\hline 7. & $\begin{array}{l}\text { Industri/ } \\
\text { perdagangan }\end{array}$ & $\sqrt{ }$ & - & $\sqrt{ }$ & $\sqrt{ }$ & $\sqrt{ }$ & $\sqrt{ }$ & $\sqrt{ }$ \\
\hline
\end{tabular}

Sumber: Karismapawirogo Explore, 2010

Selain identifikasi potensi, upaya yang dilakukan untuk mempertemukan UMKM dengan perusahaan besar merupakan langkah yang bisa segera dimanfaatkan oleh masyarakat. Walaupun masih dalam lingkup dan jumlah yang sedikit, upaya ini setidaknya bisa memberikan bukti a wa l dan harapan a k keberlangsungan model kerjasama kawasan perbatasan untuk jangka waktu ke depan.

\footnotetext{
${ }^{4}$ Kastono DS., 2011, Memory Serah Terima Koordinator BKAD Karismapawirogo 12 Mei 2009 - 12 Mei 2011,

Karanganyar: BKAD Karismapawirogo

${ }^{15}$ Yeremias T. Keban, loc.cit.
} 
Di bidang kesehatan, perjanjian kerjasama telah ditandatangani oleh para kepala dinas dari tujuh kabupaten se-Karismapawirogo bertempat di Kota Batu pada 23 Oktober 2009. Dalam perjanjian tersebut disepakati bahwa ruang lingkup kerjasama meliputi:

1. Peningkatan mutu pelayanan kesehatan;

2. Penanganan dan penanggulangan penyakit yang berpotensi menimbulkan kejadian luar biasa (KLB) dan/atau wabah;

3. Penanganan kesehatan masyarakat miskin;

4. Kegiatan bidang lain yang sesuai dengan kebutuhan.

Kemudian program/kegiatan yang telah dilaksanakan selama 2010 sebagian masih berkaitan dengan penataan organisasi, misalnya pencetakan buku profil organisasi Karismapawirogo. Selain itu, pada tahun tersebut telah melangkah pada pembuatan perjanjian di berbagai bidang dan promosi bersama potensi daerah dalam suatu pameran. Berdasarkan laporan kepengurusan yang pertama, beberapa program/kegiatan yang telah dilaksanakan pada 2010 selengkapnya adalah:

1. Penandatanganan perjanjian kerjasama bidang penanaman modal;

2. Penandatanganan perjanjian kerjasama bidang pariwisata, seni dan budaya;

3. Penyelenggaraan pameran bersama;

4. Pencetakan buku profil Karismapawirogo;

5. Studi pengalaman ke luar Jawa;
6. Temu bisnis/matching.

Dalam operasionalisasi organisasi, BKAD Karismapawirogo memiliki mekanisme yang secara hirarkis mencerminkan peran yang bersangkutan dalam organisasi. Bupati se-wilayah Karismapawirogo berperan pada level perumusan kebijakan organisasi. Dari kebijakan tersebut, kemudian diderivasikan oleh Koordinator BKAD atau di tingkat Sekretariat ke dalam strategi. Selanjutnya Sub Sekretariat dan pokjapokja merumuskan program dan melakukan koordinasi dengan pihak terkait yang relevan dengan program tersebut. Implementasi program berada pada level forum stakeholder, SKPD, dan asosiasi yang terkait dengan program tersebut. 


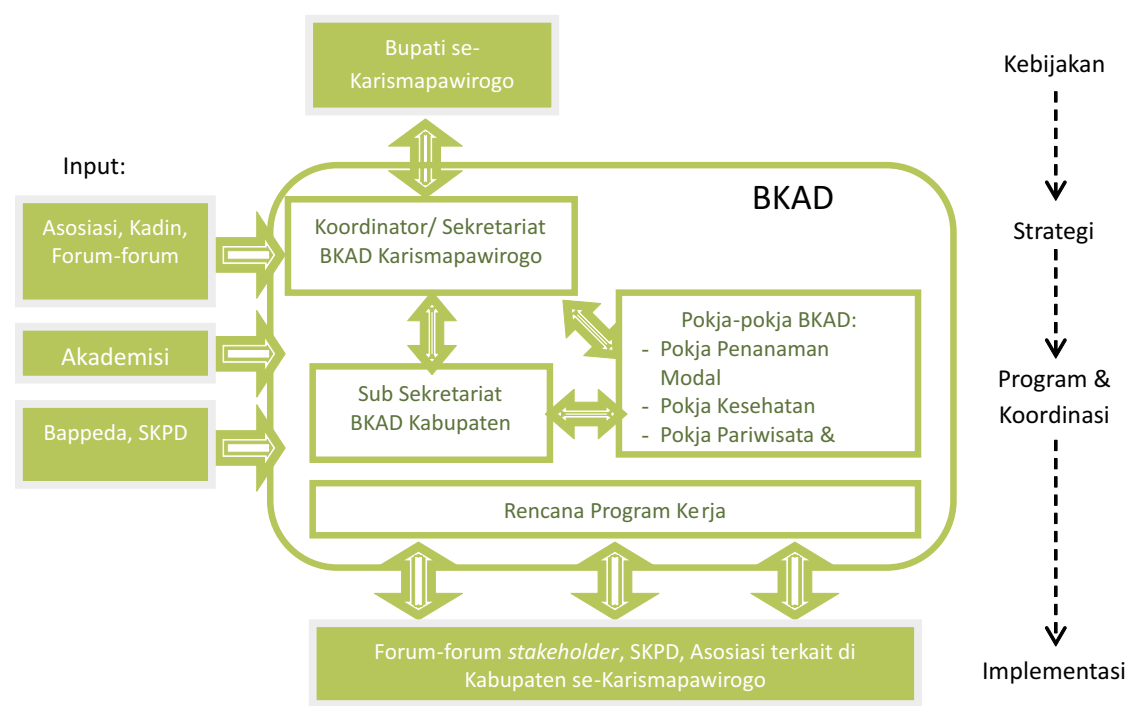

Sumber: Memory Serah Terima Koordinator BKAD Karismapawirogo 12 Mei 2009 - 12 Mei 2011, 2011

Gambar 2. Mekanisme Kerja BKAD Karismapawirogo

\section{b. Ratubangnegoro}

BKAD Ratubangnegoro merupakan wadah kerjasama antardaerah yang meliputi Kabupaten Blora, Kabupaten Tuban, Kabupaten Rembang, dan Kabupaten Bojonegoro. Penggunaan nama Ratubangnegoro merupakan akronim yang diambil dari potongan nama empat kabupaten tersebut. Kabupaten Tuban dan Bojonegoro masuk wilayah Provinsi Jatim, sedangkan Kabupaten Blora dan Rembang masuk wilayah Provinsi Jateng.

Keempat kabupaten tersebut berada di kawasan perbatasan Jatim dan Jateng wilayah utara, dimana Kabupaten Tuban (Jatim) dan Kabupaten Rembang (Jateng) memiliki kawasan pantai utara (pantura) dan dilalui jalur lalu lintas antar provinsi di kawasan pantura Jawa. Sedangkan kabupaten Bojonegoro (Jatim) dan Kabupaten Blora berada di posisi selatan dari kedua kabupaten sebelumnya, yang sebagian wilayahnya memiliki potensi hutan dan minyak dan gas bumi (migas). Dengan potensi dan kondisi geografis seperti itu maka mobilitas dan aktivitas masyarakat antar empat kabupaten tersebut seringkali melewati batasbatas wilayah administratif kabupaten bahkan provinsi.

Hal ini tentu saja memunculkan konsekuensi di berbagai aspek, dimana setiap denyut nadi kehidupan masyarakat, pemerintah dan pelaku dunia usaha pada daerah kabupaten yang berbatasan tersebut akan saling mempengaruhi dan memiliki dampak sosio ekonomi ma pun ekologi/lingkungan.

Jika dilihat dari arah pengembangan wilayahnya, Kabupaten Bojonegoro termasuk wilayah cluster yang berkembang, (dikarenakan adanya embrio kegiatan 
perekonomian) yang memungkinkan adanya konurbasi/penyatuan antar wilayah. Sedangkan perkotaan Bojonegoro sendiri diarahkan untuk pengembangan pusat kegiatan perdagangan, jasa serta kegiatan produksi pertanian dengan peningkatan hasil-hasil pertanian (agroindustri) serta pengembangan industri pengolahan minyak bumi. Sedangkan untuk Kabupaten Tuban, pengembangan wilayahnya diarahkan sebagai pusat aktivitas jasa dan perdagangan sehingga perlu dikembangkan kegiatan industri yang meliputi industri kecil, pertanian, agroindustri dan pertambangan. Kabupaten Bojonegoro dan Kabupaten
Tuban sama-sama masuk dalam wilayah pengembangan Gerbangkertasusila plus.

Letak geografis yang berdampingan, membuat daerah yang berbatasan tersebut memiliki potensi daerah yang kurang lebih sama. Kabupaten Bojonegoro yang berbatasan dengan Kabupaten Blora sama-sama memiliki potensi di bidang pariwisata/budaya, perminyakan serta pertanian. Sedangkan Kabupaten Tuban yang berbatasan dengan Kabupaten Rembang memiliki kesamaan potensi khusunya di bidang pasriwisata/budaya, pertanian, kelautan dan perikanan.

Tabel 2. Potensi Daerah Ratubangnegoro

\begin{tabular}{|l|l|c|c|c|c|}
\hline No. & \multicolumn{1}{|c|}{ Potensi } & Bojonegoro & Tuban & Rembang & Blora \\
\hline 1. & Pertambangan & - & $\sqrt{ }$ & - & $\sqrt{ }$ \\
\hline 2. & Pariwisata/budaya & $\sqrt{ }$ & $\sqrt{ }$ & $\sqrt{ }$ & $\sqrt{ }$ \\
\hline 3. & Perminyakan & $\sqrt{ }$ & - & - & $\sqrt{ }$ \\
\hline 4. & Peternakan & - & - & $\sqrt{ }$ & $\sqrt{ }$ \\
\hline 5. & Pertanian & $\sqrt{ }$ & $\sqrt{ }$ & $\sqrt{ }$ & $\sqrt{ }$ \\
\hline 6. & Kehutanan & - & - & - & $\sqrt{ }$ \\
\hline 7. & Perikanan & - & $\sqrt{ }$ & $\sqrt{ }$ & - \\
\hline
\end{tabular}

Sumber: Biro Administrasi Kerjasama Sekretaris Provinsi Jawa Timur

Oleh karena itu, dalam rangka percepatan dan perwujudan pelaksanaan kerjasama bidang pemerintahan dan pembangunan, pada 6 Juli 2006 Bupati Bojonegoro, Bupati Tuban, Bupati Blora dan Bupati Rembang membuat kesepakatan bersama dalam rangka kerjasama pembangunan daerah yang bertujuan untuk mensinergikan programprogram pembangunan dan dapat memberikan manfaat yang sebesarbesarnya bagi kesejahteraan rakyat. Kerjasama tersebut meliputi bidang kesehatan, pertambangan dan energi, kehutanan dan perkebunan, perindustrian dan perdagangan, penanaman modal, ketenagakerjaan, pendidikan dan kebudayaan, sosial, penataan ruang, pekerjaan umum, perhubungan, lingkungan hidup, pariwisata serta bidang-bidang lain sesuai kebutuhan daerah. Biaya yang timbul dari pelaksanaan kerjasama tersebut dibebankan pada APBD empat kabupaten, sehingga pelaksanaan kegiatannya harus terlebih dahulu mendapat persetujuan dari DPRD masing-masing kabupaten. 
Kerjasama regionalisasi yang diwujudkan dalam B K A D Ratubangnegoro tersebut terbentuk pada 21 september 2010, dimana BKAD Ratubangnegoro memiliki tugas mengkoordinasikan, merencanakan dan memfasilitasi kerjasama antardaerah wilayah R a tubang ne goro. D a 1 a m melaksanakan tugasnya BKAD membentuk sekretariat bersama untuk memudahkan perencanaan, pengelolaan, monitoring dan evaluasi atas pelaksanaan kerjasama antardaerah, serta memberikan masukan dan saran kepada BKAD terhadap pelaksanaan kerjasama antardaerah.

Masa jabatan kepengurusan BKAD serta Sekretariat BKAD dilaksanakan secara bergiliran selama 2 (dua) tahun sekali, dengan urutan sebagai berikut: (1) Pemerintah Kabupaten Blora; (2) Pemerintah Kabupaten Tuban; (3) Pemerintah Kabupaten Rembang, dan; (4) Pemerintah Kabupaten Bojonegoro. Adapun susunan kepengurusannya adalah sebagai berikut:

Tabel 3. Susunan Kepengurusan BKAD dan Sekretariat BKAD Ratubangnegoro

\begin{tabular}{|c|l|l|l|}
\hline No. & \multicolumn{1}{|c|}{ Jabatan Organik } & Jabatan dalam BKAD & \multicolumn{1}{|c|}{$\begin{array}{c}\text { Jabatan dalam } \\
\text { Sekretariat BKAD }\end{array}$} \\
\hline 1. & Bupati & Ketua & - \\
\hline 2. & Wakil Bupati & Wakil Ketua & - \\
\hline 3. & Sekretaris Daerah & Sekretaris & Ketua \\
\hline 4. & $\begin{array}{l}\text { Asisten yang membidangi } \\
\text { kerjasama daerah }\end{array}$ & Anggota & Wakil ketua \\
\hline 5. & Kepala Bappeda & Anggota & Sekretaris \\
\hline 6. & $\begin{array}{l}\text { Kepala Bagian yang } \\
\text { membidangi kerjasama daerah }\end{array}$ & Anggota & Anggota \\
\hline 7. & Kepala Bagian Hukum & Anggota & Anggota \\
\hline 8. & $\begin{array}{l}\text { Kepala SKPD yang membidangi } \\
\text { Keuangan }\end{array}$ & Anggota & Anggota \\
\hline 9. & $\begin{array}{l}\text { Kepala SKPD yang membidangi } \\
\text { Pengelolaan Aset Daerah }\end{array}$ & Anggota & Anggota \\
\hline 10. & Kepala Inspektorat Daerah & Anggota & \\
\hline
\end{tabular}

Sumber: Biro Kerjasama Provinsi Jawa Timur

Ada beberapa rencana program/kegiatan yang dibuat melalui kerjasama tersebut, antara lain sebagai berikut:

1. Pembangunan infrastruktur seperti pembangunan jembatan Biting dan Giyanti yang menggunakan dana sharing antara Kabupaten Blora dan Kabupaten Bojonegoro;

2. Penataan rest area di kawasan perbatasan Rembang dan Tuban;
3. Investasi pariwisata;

4. Upaya penyelesaian sengketa perbatasan pada daerah penambangan pasir kwarsa diwilayah Kec. Bancar (Tuban) dengan Kec. Sarang (Rembang);

5. Pengembangan kapasitas pabrik gula mini, yang mana bahan baku tanaman tebunya ditanam di wilayah perbatasan Kabupaten Tuban dan Bojonegoro; serta 
6. Tata pengaturan dan pengelolaan air pada daerah aliran sungai (DAS) Bengawan Solo (pada musim kemarau) yang pengelolaannya digunakan untuk irigasi persawahan maupun bahan baku air bersih.

Salah satu dasar pelaksanaan kerjasama BKAD Ratubangnegoro adalah Keputusan Bersama Gubernur Jateng dengan Gubernur Jatim Nomor 01 Tahun 2001 dan Nomor 42 Tahun 2009 tentang Kerjasama Pemerintah Provinsi Jawa Tengah dengan Provinsi Jawa Timur. Keputusan bersama ini dibuat dengan pertimbangan bahwa kedua provinsi memerlukan kebersamaan dalam pelaksanaan pemerintahan, pembangunan dan kemasyarakatan secara terpadu, serasi dan seimbang sehingga dapat memberikan manfaat yang sebesarbesarnya bagi kesejahteraan rakyat di kedua provinsi.

Kerjasama ini meliputi aspek perencanaan, pelaksanaan, pengendalian dan evaluasi yang dijabarkan lebih lanjut dalam bentuk program-program bersama dan diatur lebih lanjut dengan perjanjian kerjasama. Selanjutnya biaya yang timbul dari kerjasama tersebut dibebankan pada: (1) Anggaran Pendapatan dan Belanja Negara, (2) Anggaran Pendapatan dan Belanja Daerah Provinsi Jateng, (3) Anggaran Pendapatan dan Belanja Daerah Provinsi Jatim, serta (4) sumber dana lain yang sah dan tidak mengikat.

Berangkat dari keputusan bersama di atas, Pemerintah Provinsi Jatim yang diwakili oleh Badan Koordinasi Wilayah (Bakorwil)
Pemerintahan dan Pembangunan Bojonegoro melakukan rapat kordinasi sebagai upaya fasilitasi pelaksanaan kerjasama antardaerah bidang pemerintahan dan pembangunan kabupaten wilayah Ratubangnegoro pada 27 April 2011. Fasilitasi ini diharapkan dapat menjadi percepatan pelaksanaan kerjasama bidang pemerintahan dan pembangunan daerah perbatasan Jatim dan Jateng dalam wilayah Ratubangnegoro.

Tujuan dari kegiatan fasilitasi ini adalah untuk mempertemukan kepala SKPD Bidang Pembangunan di kabupaten wilayah Ratubangnegoro, dengan Kepala SKPD Provinsi Jatim dan Jateng, guna melakukan pembicaraan awal atau penjajakan untuk merencanakan perjanjian kerjasama bidang pembangunan sesuai dengan bidang tugasnya masingmasing. Selain itu fasilitasi ini juga dilakukan dengan maksud untuk melakukan evaluasi terhadap kerjasama bidang penanaman modal kabupaten wilayah perbatasan Jatim d a n J a teng d i kaw a sa n Ratubangnegoro.

Keberadaan Pemerintah Provinsi (Jatim dan Jateng) dalam hubungan kerja antar kabupaten di kawasan perbatasan berperan sebagai fasilitator. Hal ini ditunjukkan dengan dukungan yang diberikan oleh kedua provinsi yaitu antara lain:

1. Dukungan kontribusi peran (sharing) dalam pelaksanaan kerjasama pembangunan sarana keciptakaryaan, yaitu pendanaan program terpadu, penyediaan lahan dan proses perijinan dan 
pemberdayaan swasta dan masyarakat;

2. Dukungan data dan informasi yang obyektif dan valid tentang permasalahan dan kondisi pelayanan prasarana/sarana sebagai acuan identifikasi kebutuhan dan penyusunan program terpadu lintas kabupaten/kota;

3. Dukungan yang kooperatif terhadap pelaksanaan pemanfaatan ruang/lahan kabupaten/kota yang dituangkan dalam RTRW masingmasing provinsi; serta

4. Bentuk goodwill dan political will dari pemerintah provinsi dalam menunjang keterpaduan pembangunan, khususnya di wilayah perbatasan, dengan mengeliminir egoisme kewilayahan untuk membuka jalinan kerjasama lintas kabupaten/kota secara berkelanjutan.

\section{Percepatan Pembangunan dan Pelayanan Publik di Kawasan Perbatasan}

E k s i s te n s B K A D Karismapawirogo dan BKAD Ratubangnegoro merupakan upaya pengelolaan kawasan perbatasan antardaerah secara bersama-sama. Pembentukan kedua BKAD tersebut dimungkinkan karena kerjasama antardaerah di kawasan perbatasan tersebut disepakati berlaku selama 5 (lima) tahun, sebagaimana telah diatur pada Pasal 24 PP No. 50 Tahun 2007 tentang Tata Cara Pelaksanaan Kerja
Sama Daerah, dan bukan merupakan perangkat daerah.

Berdasarkan pendapat yang dikatakan Gary D. Taylor, bisa dikatakan bahwa keberadaan kedua badan tersebut lebih mendekati wujud jointly-formed authorities. ${ }^{16}$ Dalam hal kelembagaan dan kepengurusan, ada kemiripan antara kedua BKAD tersebut dimana pengelolaan lembaga ini dilakukan sendiri oleh para pejabat di lingkungan pemerintah daerah, yang diwadahi dalam suatu Sekretariat BKAD sebagai koordinator pelaksanaan kerjasama antardaerah, tidak diserahkan kepada manajer profesional yang independen.

Walaupun lebih mendekati jointly-formed authorities, namun ada juga penerapan fee for service contract (service agreements) dimana penyelenggara pelayanan publik satu daerah bisa melayani masyarakat dari daerah lain. Hal ini bisa terlihat pada Perjanjian Kerjasama para Kepala Dinas Kesehatan se-Karismapawirogo. Dengan kesepakatan tersebut maka setiap pasien masyarakat miskin di kawasan perbatasan tersebut bisa mendapatkan pelayanan kesehatan di rumah sakit terdekat (lintas kabupaten) setelah mendapatkan rujukan dari puskesmas. Bahkan untuk kasus gawat darurat maka pasien masyarakat miskin bisa langsung menuju rumah sakit terdekat. ${ }^{17}$

Pola kerjasama pelayanan publik lintas batas tersebut sebagai

\footnotetext{
${ }^{16}$ Gary D. Taylor, loc.cit.

${ }^{17}$ Pasal 5 Perjanjian Kerjasama antar Kepala Dinas Kesehatan se-Karismapawirogo tahun 2009, dalam Lampiran Memory Serah Terima Koordinator BKAD Karismapawirogo 12 Mei 2009-12 Mei 2011.
} 
upaya mendekatkan unit pelayanan kepada masyarakat yang tidak terjangkau oleh unit pelayanan di daerah domisilinya. Janet V. Denhardt dan Robert B. Denhardt ${ }^{18}$ dalam kompilasi berbagai pemikiran yang dirumuskan dalam model pelayanan publik baru (new public service) antara lain menyebutkan seek the public interest (mencari kepentingan publik). Bahwa memberikan kontribusi kepada masyarakat secara kolektif melalui penciptaan kepentingan dan tanggungjawab bersama. Berdasarkan pemikiran tersebut maka pelayanan kesehatan terhadap masyarakat sebagai public interest yang ditangkap oleh daerah di kawasan Karismapawirogo dan ditanggung secara kolektif sebagai tanggungjawab dan kepentingan bersama.

Selain mutual understanding and benefit, dalam pelaksanaan kerjasama antardaerah diperlukan juga adanya simbiosis, sinergi, dan integritas para aktor yang terlibat dalam pelaksanaan kerjasama tersebut. ${ }^{1 .}$ Apabila semua itu bisa terpenuhi maka keberlangsungan kerjasama antardaerah bisa terpelihara dalam rangka percepatan pembangunan daerah dan perbaikan pelayanan publik.

Sebagai BKAD yang relatif baru, Karismapawirogo dan Ratubangnegoro merupakan sebuah upaya untuk mengelola kawasan perbatasan secara bersama dalam rangka percepatan pembangunan dan peningkatan pelayanan publik di kawasan perbatasan. Kedua lembaga tersebut harus bisa menjadi organisasi pembelajar dalam mengelola kawasan perbatasan dengan segala potensi dan keterbatasannya. Keberlangsungan kerjasama tersebut akan diuji apakah semua daerah yang menjalin kerjasama mendapatkan manfaat dari pelaksanaan kerjasama tersebut. Masing-masing pihak akan memelihara keberlangsungan kerjasama apabila memberikan manfaat bagi masingmasing daerah. ${ }^{20}$

Namun sayangnya implementasi kesepakatan kerjasama ke dalam level program/kegiatan konkrit yang manfaatnya langsung bisa dirasakan oleh masyarakat masih minim. Dari 15 bidang yang telah disepakati dalam lingkup Karismapawirogo, tercatat beberapa bidang yang sudah ditindaklanjuti pada level kepala SKPD yaitu bidang kesehatan, pengembangan penanaman modal bidang pertanian, pertambangan, kehutanan, dan pariwisata, serta pengembangan kepariwisataan dan kebudayaan.

Sedangkan di kawasan Ratubangnegoro masih belum menunjukkan geliat pelaksanaan program kerja yang kongkrit dan yang bisa dimanfaatkan oleh masyarakat. Seperti rencana pembangunan jembatan Bitting dan jembatan Giyanti yang menggunakan dana sharing antara Kabupaten Blora dan Kabupaten Bojonegoro, namun belum dapat terlaksana karena belum dianggarkan

\footnotetext{
${ }^{18}$ Denhardt, Janet V. dan Robert B. Denhardt, loc.cit.

${ }^{19}$ Robert Anton, konsultan Pemerintah Provinsi Jatim dalam FGD Pola Hubungan Kerja Antar provinsi, Bappeda Jatim, Surabaya, 28 Juni 2011

${ }^{20}$ Yeremias T. Keban, op. cit
} 
secara bersama-sama oleh kedua daerah.

\section{P e r m a s l a h a d a l a m Implementasi Kerjasama}

Beberapa permasalahan atau kendala muncul dalam praktek kerjasama di kawasan perbatasan Jatim dan Jateng tersebut. Pertama, susunan kepengurusan BKAD serta Sekretariat BKAD yang berasal dari pejabat struktural pemerintah daerah, menjadikan dilematika dalam operasionalisasi lembaga tersebut. Di satu sisi, keberadaan pejabat struktural pemerintah daerah dalam struktur lembaga BKAD bisa mempermudah mobilitas atau penggerakan sumber daya karena akses dan kewenangan yang dimilikinya. Tetapi di sisi lain, keterlibatan mereka dalam operasionalisasi BKAD menjadi kurang fokus karena kesibukan lain berkaitan jabatan strukturalnya di pemerintah daerah, hal ini bisa menjadikan pelaksanaan kegiatan kerjasama kurang maksimal.

Hal ini nampak dari belum jelasnya program yang disusun oleh kesekretariatan BKAD serta belum adanya perjanjian kerjasama bidang pembangunan (kecuali bidang kesehatan dan pengembangan penanaman modal), yang merupakan tindak lanjut dari kesepakatan bersama antara Kabupaten Blora, Tuban, Rembang dan Bojonegoro, yang ditandatangani pada 6 Juli 2006.

Kedua, belum sinkronnya aturan antara kedua daerah (Provinsi Jatim dan Jateng). Contohnya adalah kasus penambangan pasir, Pemprov Jatim sudah memiliki Perda yang mengatur mengenai penambangan pasir, tidak demikian dengan Provinsi Jateng. Hal ini menjadi kendala terhadap usaha Pemprov Jatim untuk melakukan penertiban terhadap penambang pasir yang menggunakan alat mekanik (mesin pompa) di wilayah Sungai Bengawan Solo (pada waktu musim kemarau), dimana sungai tersebut berada di perbatasan Jatim dan Jateng. Apabila Pemprov Jatim melakukan penertiban, maka para penambang beralasan bahwa mereka berada di wilayah Jateng.

Ketiga, belum dianggarkannya secara bersama-sama program serta kegiatan yang akan dilaksanakan, sehingga sampai sekarang masih ada kegiatan yang belum dilaksanakan, seperti misalnya pelaksanaan pembangunan jembatan Bitting dan jembatan Giyanti. Padahal kedua jembatan tersebut sangat dibutuhkan oleh masyarakat sekitar sebagai penghubung antara Kabupaten Blora dan Kabupaten Bojonegoro. Selain itu penganggaran pada tingkat provinsi juga belum banyak menyentuh untuk daerah wilayah perbatasan, khususnya wilayah Ratubangnegoro.

Keempat, belum adanya sinergi perencanaan kegiatan antardaerah, seperti jalan kabupaten lintas poros kecamatan wilayah perbatasan JatimJateng. Belum ada sinkronisasi dan sinergitas perencanaan dalam pemeliharaannya, sehingga kualitas maupun pelaksanaan pemeliharaan jalan tersebut masih mengalami perbedaan. Bukan hanya pada tahapan perencanaan, tetapi juga dalam pelaksanaan. 


\section{F. PENUTUP}

\section{Simpulan}

Berdasarkan uraian temuan lapangan dan pembahasan di atas bisa dirumuskan beberapa simpulan sebagai berikut:

a. Praktek kerjasama antardaerah untuk meningkatkan pembangunan dan pelayanan publik di kawasan perbatasan Jatim dan Jateng diwujudkan dengan membentuk badan kerjasama (non SKPD), sebagai lembaga koordinasi pelaksana kerjasama yang selanjutnya pelaksanaan teknis operasional dilakukan oleh masingmasing SKPD sesuai bidang urusan yang dikerjasamakan. Di kawasan perbatasan wilayah utara, dibentuk BKAD Ratubangnegoro, sedangkan di kawasan perbatasan wilayah tengah dan selatan dibentuk BKAD Karismapawirogo.

b. Kepentingan untuk maju bersama dan menyelesaikan masalah secara bersama antardaerah merupakan alasan mendasar terwujudnya kerjasama. Kerjasama antardaerah bisa membuka akses masyarakat terhadap pelayanan publik yang lebih dekat sehingga keterbatasan akses terhadap fasilitas pelayanan publik di daerah domisilinya bisa terpecahkan dengan terbukanya akses ke daerah lain. Terbukanya akses tersebut mempermudah dan meringankan beban masyarakat dan juga pemerintah daerah;

c. Efektivitas pelaksanaan kerjasama di kawasan perbatasan tersebut masih rendah, terlihat masih minimnya tindak lanjut bidangbidang yang disepakati untuk dikerjasamakan serta persoalan sinergitas dan sinkronisasi perencanaan antar daerah. Sinergitas dan sinkronisasi perencanaan antardaerah sangat berpengaruh dalam pelaksanaan kerjasama antardaerah terutama ketika sudah menyentuk level teknis operasional di masing-masing sektor. Namun demikian, prospek ke depan masih cukup terbuka untuk operasionalisasi kerjasama dalam bentuk kegiatan yang konkrit dalam rangka akselerasi pembangunan kawasan perbatasan dan meningkatkan kualitas pelayanan publik;

\section{Saran}

Berdasarkan uraian di atas, disarankan beberapa hal yang perlu ditindaklanjuti oleh pemerintah daerah yang terlibat dalam kerjasama antardaerah baik tingkat provinsi maupun kabupaten, yaitu:

a. Untuk menindaklanjuti kesepakatan kerjasama antar daerah diperlukan komitmen bersama antardaerah sehingga bidangbidang yang telah ditetapkan dalam kesepakatan kerjasama bisa direalisasikan dalam bentuk program dan kegiatan yang konkrit dan bisa dimanfaatkan oleh masyarakat.

b. Agar operasionalisasi BKAD dapat berjalan lebih optimal, perlu 
melibatkan aktor profesional independen dari luar pemerintahan sebagai pengurus lembaga tersebut sehingga bisa lebih fokus dalam pelaksanaan program/kegiatan kerjasama;

c. Sinkronisasi peraturan perundangan tingkat provinsi dan kabupaten di kawasan perbatasan menyangkut potensi persoalan yang terjadi di kawasan tersebut sehingga persoalan yang muncul bisa segera dipecahkan di level bawah;

d. Sinkronisasi perencanaan pembangunan daerah dengan melakukan pertemuan perencanaan pembangunan bersama, misalnya musrenbang kawasan perbatasan yang membahas hal-hal yang berkaitan dengan pengembangan dan pelayanan publik di kawasan perbatasan;

\section{DAFTAR PUSTAKA}

Anonim, 2004, Ringkasan Eksekutif Penelitian tentang Permasalahan Wilayah Perbatasan Kabupaten / Kota di Jawa Timur, Surabaya: Badan Penelitian dan Pengembangan Provinsi Jawa Timur bekerjasama dengan Lembaga Penelitian Universitas Airlangga.

Dawud, Joni, et. al., 2003, Hubungan Kerjasama Pembangunan Antar Daerah, Bandung: PKDAILAN.

Denhardt, Janet V. dan Robert B
Denhardt, 2007, The New Public Service: Serving, Not Steering. New York: M.E. Sharpe, Inc.

Dunn, William N., 2003, Pengantar Analisis Kebijakan Publik, Yogyakarta: Gama Press , (Terj.) Edisi kedua.

Kastono DS., 2011, Memory Serah Terima Koordinator BKAD Karismapawirogo 12 Mei 2009 - 12 Mei 2011, Karanganyar: BKAD Karismapawirogo

Keban, Yeremias T., 2009, Kerjasama Antar Pemerintah Daerah dalam Era Otonomi: Isu, Strategis, Bentuk dan Prinsip, Dapat dibuka di situs: http://www.bappenas.go.id/no de/48/2258/kerjasama-antarpemerintah-daerah-dalam-eraotonomi-oleh-yeremias-tkeban-/, diunduh 25 Januari 2011

Tarigan, Antonius, Kerjasama Antar Daerah (KAD) Untuk $P$ e $n$ i $n$ g $\quad k$ a $\quad t \quad a \quad n$ Penyelenggaraan Pelayanan Publik Dan Daya Saing Wi l a y a $h, \quad \mathrm{~d}$ a $1 \mathrm{a} \mathrm{m}$ http://bulletin.penataanruang. net/index.asp?mod $=$ fullart\&i dart $=161$, diunduh 25 Januari 2011.

Zakiyah, Siti, 2007, Kinerja Pelayanan Publik dan Kebutuhan Penataan Kelembagaan Pengelolaan Wilayah Perbatasan di Kalimantan, dalam Jurnal Borneo 
Adminsitrator Vol. 3, No. 1/2007, hal. 760-761.

\section{Website}

http://nasional.kompas.com/read/2009 /04/03/09111381 diunduh 11 Oktober 2011

\section{Peraturan Perundang-Undangan}

Keputusan Menpan No. 63 Tahun 2003 tentang Pedoman Umum Penyelenggaraan Pelayanan Publik

Peraturan Pemerintah Nomor 50 Tahun 2007 tentang Kerjasama Antar Daerah.
Permendagri No. 22 Tahun 2009 tentang Petunjuk Teknis Tata Cara Kerja Sama Daerah.

UU No. 32 Tahun 2004 tentang Pemerintahan Daerah

UU No. 25 Tahun 2009 tentang Pelayanan Publik

\section{Diskusi}

Focus Group Discussion (FGD) Kajian Pola Hubungan Kerja Antar Daerah di Kalimantan, Bappeda Provinsi Jawa Timur, Surabaya, 28 Juni 2011. 